\title{
THE IDEA OF A SYSTEM INCREASING FLIGHT SAFETY
}

\author{
Tomasz Rogalski \\ Rzeszow University of Technology, Dept. of Avionics and Control, Al. Powstancow W-wy 8, 35-959 Rzeszow, Poland \\ E-mail: orakl@prz.edu.pl
}

Received 07 September 2010; accepted 01 October 2010

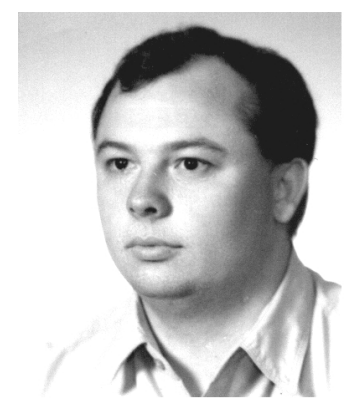

Tomasz ROGALSKI, PhD Eng

Education: 1996 - Rzeszow University of Technology.

Affiliation and functions: MSc degree in 1996, PhD degree in 2004, Rzeszow University of Technology, Faculty of Mechanical Engineering and Aeronautics, specialisation: Aircraft Control Systems.

Research interest: aircraft control, UAV aircraft control.

Present position: researcher and lecturer at Rzeszow University of Technology since 1996. Rzeszow University of Technology, Faculty of Mechanical Engineering and Aeronautics, Department of Avionics and Control Systems. Phone: +48 17865 1477, fax. +48 178544319 .

\begin{abstract}
This paper presents a conception of an airborne control system that can increase the safety of a general aviation aircraft. Sample threats appear on board the general aviation airplane discussed in the paper. The system monitors some events and flight parameters in the cockpit and can take some actions protecting the plane against threats if recognised as necessary. The paper presents sample actions fly-by-wire control systems can take to protect a plane against some threats on board. The system can modify a pilot's controls to correct flight and if it is not enough the system can disengage the pilot to autonomously fly the plane to the nearest safe airport
\end{abstract}

Keywords: general aviation, flight safety, automatic flight.

\section{Introduction}

General aviation aircraft (GAA) have become a popular mean of transport in recent years. More and more people use them to travel between sites. Travel with GAA is executed for many purposes. GAA have started to be used for business, sport, and also fun. Recent technological development has caused the availability of GAA to increase significantly.

The increased use of GAA has created a large group of people who fly GAA but are not professional pilots (Tomczyk 2003; Tomczyk 2008). The health requirements pilots of GAA must meet have also been reduced over the past several years.

These phenomena cause the discussion to arise of how to assist less skilled pilots to fly safely. One proposed scenario assumes the development of new types of onboard equipment. According to this scenario the plane should be equipped with systems assisting the pilot to take correct actions. Many aviation and scientific centres the world over have started working under systems that can assist non-professional pilots during flight to safely reach their destination. These systems approach the problem of assistance to the pilot individually.

The flight safety of GAA depends on many elements. Factors such as weather, technique, piloting skill, and the pilot's health can generate some threats on board the plane. September 11 demonstrated that planes could be also used as a weapon with very tragic effects. Other example is the tragedy of the Cypriot airplane over Athens when the crew lost consciousness. Hijacking or health problems of the crew can also happen on a general aviation plane (Wilkinson et al. 1999; General... b). Big aircraft traffic is well monitored nowadays. Numerous civilian and military programs has been started by governments and aviation companies all over the world (General... a; Report... 2001). Their mission is to protect general aviation against terrorism events and other threats (Security... ; Safe...; General... a).

General aviation aircraft are in general unfortunately not the priority in those programs (Security... ; Safe... ; General... a). If we would like to create GAA traffic rules for the future, as for instance the SESAR program does, 
how to protect GAA against possible threats should be discussed (Single...). One possible way to solve this problem is however providing technical protection.

The paper presents a generic concept of some solutions intended for control systems that if applied could increase the flight safety of general aviation aircraft. The main assumption is that the system must assist the pilot and correct his actions if necessary.

It must be pointed out that the main goal of this paper is not to provide a manual for builders to construct a complete secure system. Only the general shape of some elements of the control system are proposed in this paper.

\section{Threats}

The flight of a plane is a phenomenon, which goes in strict conjunction with many kinds of threats. There are threats arising from a pilot's health condition, a pilot's intentions (e.g. terrorism), technical problems, etc. (General... b). This paper focuses on selected threats coming from two sources: the health and intensions of a pilot.

The health requirements non-professional pilots have to meet are significantly less than those for professionals. The probability that a non-professional pilot's health problems might appear during flight is much higher than in the case of professional pilots. This problem, in conjunction with the continually increasing air traffic of airplanes piloted by non-professionals, must be noticed and discussed. Moreover, some means to protect a plane against hazards arising from a pilot's health problems should be looked for. The discussion about hazards arising from a pilot's health must take into consideration two main cases. The first of them means the pilot loses consciousness and cannot control the plane and the plane's systems. The second case is more complicated because the pilot is still active but his activity is not correct (for example the pilot is drunk or has used drugs) and can lead the plane into dangerous situations. He takes actions that are improper, stupid, and often even dangerous. The system should recognize both cases and take action. To meet the foregoing requirement, the system should monitor a pilot's activity during the flight to provide an answer to this question: Is the pilot able to control the plane or not?

September 11 proved that a hijacked plane could be a very effective weapon. Airlines have developed security systems to avoid similar events in the future. General aviation aircraft are unfortunately not involved in such careful security procedures as big airplane are (Security... ; Safe... ; General... a). A general aviation plane could be used as a weapon by terrorists for instance. The system should therefore analyze whether the flight is creating any threat. The plane's position, altitude, and other flight parameters supported by a declared flight plan and databases of restricted areas and other specific data allow the system to say the flight is safe. If the system recognizes the pilot flying to a restricted region, flying too low to the ground, or engaging in some other risky behaviour, it can take some action to correct the flight as a first step and take the control over the plane as the next step.

\section{The scenario of system operations}

The system discussed in this paper performs several subtasks to complete the main objective. It monitors the pilot's activity and flight parameters to collect the data necessary to correctly diagnose threats appearing on board the plane. If a threat is identified, the system decides whether any action is necessary to protect the plane. The system works in two steps. The system slightly modifies the pilot's controls to improve the flight in the first step. If small corrections of the pilot's controls are enough, that means the end of system intervention. If they aren't enough, however, the system can decide the pilot has to be disengaged totally. Then in the second step the system starts to fly autonomously (McLean 2003). The activity of the system follows the following chain of operations:

1. The continuous monitoring of a pilot's activity and a plane's flight parameters.

2. Identification of a threat.

3. Corrections of the pilot's commands.

4. System disengages the pilot totally and secures the basic flight parameters: altitude, speed, attitude etc.

5. The route to a selected airport with the use of a specified algorithm is calculated.

6. The system autonomously guides and controls the plane to the selected airport.

7. Automatic landing is the last element of the flight.

\section{General structure of the system}

This paper presents the general conception of an onboard system that monitors some events on board a plane and can take some protective actions if it recognises that they are necessary. Selected aspects of the functionality of such a system followed by technical solutions are presented in the paper.

The system can disengage the pilot to autonomously control the plane to reach the nearest safe airport for instance. This assumption implies the system has to be made in fly-by-wire technology (Rogalski et al. 2005; Tomczyk 2003). The pilot controls the plane with the use of an on-board control computer (Fig 1).

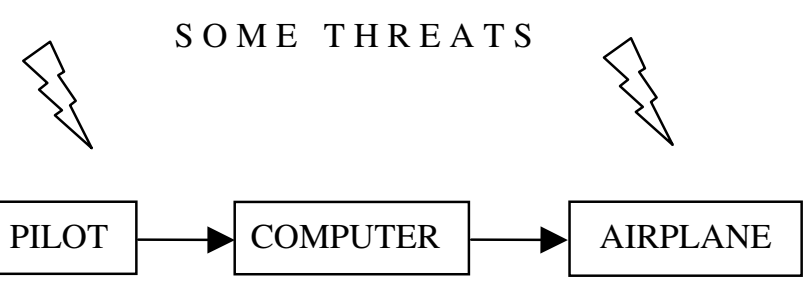

Fig 1. The schematics of the system

There is no mechanical connection between the stick and control surfaces in such a system. The pilot's controls 
are sent to the on-board computer. The computer interprets them and can modify if it is decided that it is necessary for flight safety.

On the basis of information acquired from both supplementary subsystems and indicators, the computer decides whether the threat detected needs some actions to protect the airplane. The conception of the system presented in this paper implies that one of the most responsible elements of the entire system is software. The proper realisation of the main purpose requires the following software modules:

- Detection of threats - monitors the state of the airplane and activity of the pilot to determine whether any threat has appeared.

- Analysis of the situation - analyses the threat, pilot's activity, and flight parameters to decide whether the system has to take any action.

- Modification of the pilot's control - modifies control signals sent to control surfaces or totally takes control of the aircraft to avoid the hazard identified.

- Navigation and autopilot-automatically determines the 3-D position of the aircraft, calculates the route to a safe airport, and autonomously guides the aircraft if necessary.

- Maintenance of databases - extracts information about terrain, obstacles, airports, etc.

\section{Sample threat detection}

There are several situations on board aircraft generating different threats. A sample is presented later in this chapter.

The system should identify a pilot's health problems because they can produce very dangerous results. Estimation of pilot's health is in fact a major independent task. Many scientific research teams all over the world are work on it. The estimation of a pilot's health is not the subject of this paper, but the results of research must be used in the structure and working philosophy of the system that is being presented to estimate the condition of a pilot's health. On-board sensors acquire information and transfer them to a module that analyses a pilot's state and takes decisions concerning his activity. The analysis of a pilot's health is realised in several areas.

The first of them is the testing of a pilot's movements (hands, head etc.). Movement indicators can be used to provide some necessary information. It can provide an answer to the question of whether the pilot has lost consciousness for instance. The system can test not only a pilot's movements but also whether the pilot is using onboard equipment, navigation systems, communication systems, etc.

The second test checks whether the pilot can correctly perform the tasks the system demands. The system requires the pilot to take some specific actions and checks whether the pilot's responses are correct.

The third way of testing a pilot's behaviour is monitoring the plane's flight parameters. The system should take some actions to correct the state of the aircraft if any problem is recognised. For instance, if the pilot dangerously reduces altitude the system can modify the aircraft' handling qualities to cause permanent decrease to become more and more difficult (Tomczyk 2003). If minimum altitude is reached, the system should treat this situation as a threat and should take corrective action. This goal can be achieved by the use of an active stick for instance. The active stick is recognised as a stick with a specific force feedback subsystem. Force feedback uses information about the plane's state and computational algorithms to modify stiffness of the stick and moves its neutral position. Figure 2 presents a sample action the system takes to protect the plane against flight too low to the ground. The pilot must more and more move the stick forward to keep constant altitude. In fact, the pilot senses the plane wants to fly up.

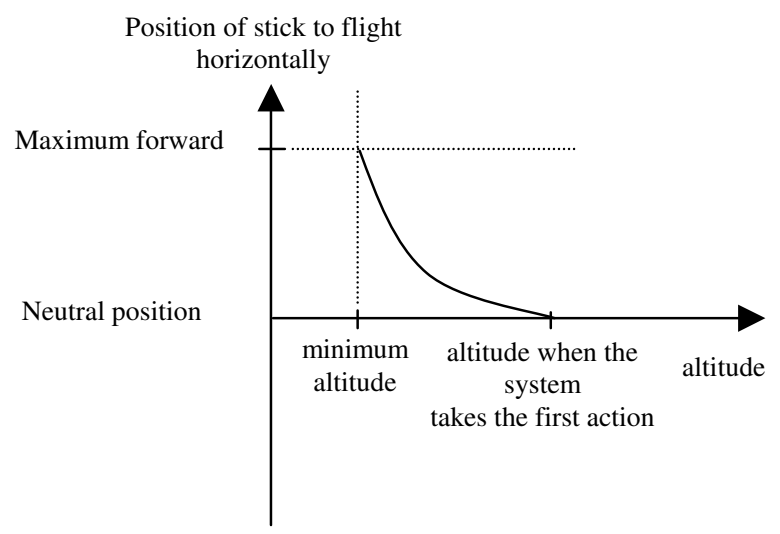

Fig 2. Sample of modification of airplane handling qualities if low altitude threat is detected

The system should continuously check whether plane's predicted trajectory is going directly toward any restricted region. If yes, a new track leading the plane out of such an area should be permanently calculated. If the system senses the plane is too close to the region, it should take action to slightly modify the track to bypass the restricted area (Fig 3).

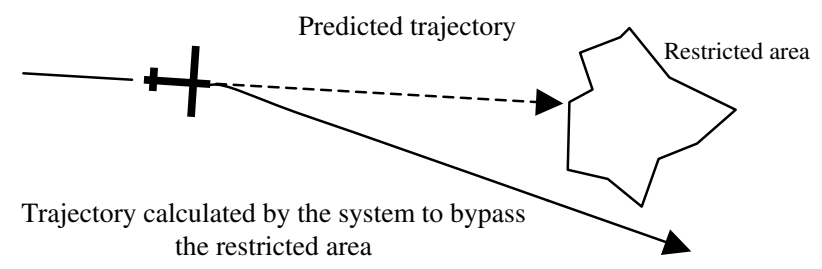

Fig 3. The system wants to bypass the restricted area

The system modifies pilot's control to force the soft turn to reach the newly calculated trajectory for instance. The pilot senses the plane has some tendency to tilt to the wing in the effect. The pilot can correct roll angle and keep the wings horizontal, but he needs to constantly increase deflection of the stick or rotation of the control wheel. When the system recognises the plane is too close to the restricted area and the pilot stubbornly fights against the system's corrections is treated as a threat. The system takes protective action and disengages the pilot. 
Finally the system autonomously controls the plane, flying to the selected airport.

General aviation aircraft are not intended for aerobatic flight in general. Pilots must have the possibility to perform dynamic and substandard manoeuvres of course - in an emergency for instance. But such flight cannot be standard. Therefore the system must monitor flight parameters and pilot activity. If it recognises that the flight is too dynamic for a long time and flight parameters reach critical values as an effect of the pilot's control, the system must inform the pilot and eventually take actions protecting against dangerous flight. The system could use a variable stick's gain to reduce deflections of control surfaces for instance (Fig 4).

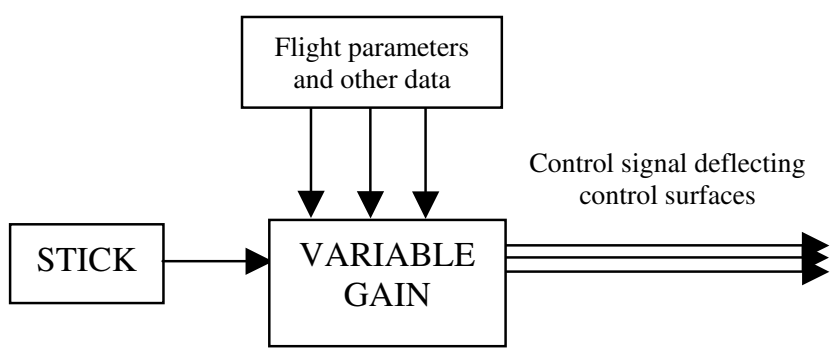

Fig 4. Variable gain of stick is an effect of flight parameters

Other protective mechanisms could activate restrictions of selected flight parameters (e.g. pitch angle, roll angle airspeed, roll rate, pitch rate). The control system could modify the pilot's controls to keep selected flight parameters in specific ranges. Sample restrictions are put in table. The data in table is a proposition only and must be adapted to specific cases.

But if the pilot still uses the stick too dynamically, it could mean he wants to control the airplane hazardously. The system should take control of the plane and fly to a safe airport.

Table. Sample restrictions put on selected flight parameters

\begin{tabular}{|l|c|c|}
\hline Flight parameter & Minimal value & Maximal value \\
\hline Pitch angle & $-15[\mathrm{deg}]$ & $15[\mathrm{deg}]$ \\
\hline Roll angle & $-15[\mathrm{deg}]$ & $15[\mathrm{deg}]$ \\
\hline Roll rate & $-5 \mathrm{deg} / \mathrm{sec}$ & $5 \mathrm{deg} / \mathrm{sec}$ \\
\hline Pitch rate & $-5 \mathrm{deg} / \mathrm{sec}$ & $5 \mathrm{deg} / \mathrm{sec}$ \\
\hline Airspeed & 1.2 stall speed & $\begin{array}{c}0.8 \text { manoeuvring } \\
\text { speed }\end{array}$ \\
\hline
\end{tabular}

\section{Databases}

In the idea presented in this paper, the system autonomously projects the route (3D longitude, latitude and altitude) and guides the plane to the end point (including landing in the future). The system must therefore know lots of information about the terrain the plane is flying over, about obstacles, restricted areas, the plane's characteristics (fuel consumption, gradient of climbing, etc.), and airports (runways, navigation aids, etc.). On the basics of those data the algorithm should calculate the optimal route for the plane to land safely.
All specified databases necessary for the system are widely available currently, and it is not a technical problem to implement them into an informatics system like the system presented in this paper.

\section{Conclusion}

General aviation airplanes used as a means of transport for business, recreation, or fun improve the lives of humans. They unfortunately also bring several hazards. Systems mounted on board GAA should therefore reduce those hazards. Technologies currently existing give engineers and others working in aviation safety and security instruments the ability to project and develop systems reducing the effects of the hazards pointed out.

There are several ideas presented in this paper, which if applied in airborne systems could improve flight safety and security of general aviation aircraft.

\section{References}

General Aviation as a Terror Weapon [online], b. Available from Internet: <http://www.officer.com/web/ online/Technology/20\$51227>.

General Aviation Security: Report of United States Government Accountability Office [online], a. Available from Internet: <http://www.gao.gov/new.items/ d05144.pdf>.

McLean, D. 2003. Operational requirements for fully automatic flight, Aircraft Engineering and Aerospace Technology 75: 570-574.

Report of the Secretary of Transportation to the United States Congress Pursuant to Section 132 (b) of the Aviation and Transportation Security Act (PL 10771). 2001[online]. Available from Internet: <http:// www.nonoise.org/library/generalav/Congress.pdf>.

Rogalski, T.; Dołega, B. 2005. Flying tests of control system improving aircraft's handling qualities, in 6 th International Multidisciplinary Conference. Baia Mare, Romania: Scientific Bulletin 2: 667-672.

Rogalski, T.; Dołega, B. 2008. Diagnostics of fly-by-wire control system, Aviation 12(2): 41-45. DOI: 10.3846/1648-7788.2008.12.41-45.

Safe Automatic Flight Back and Landing of Aircraft [online]. Available from Internet: <http://www.sofia. isdefe.es $>$.

Security of Aircraft in the Future European Environment [online]. Available from Internet: <http://www.safee. reading.ac.uk $>$.

Single European Sky ATM Research [online]. Available from Internet: <http://ec.europa.eu/transport/air/ sesar/sesar_en.htm>.

Tomczyk, A. 1998. Concept for simplified control of general aviation aircraft, in Word Aviation Conference, SAE/ACAA, Anaheim, CA, 1998. Paper no 985551.

Tomczyk, A. 2003. Experimental fly-by-wire control system for general aviation aircraft, in AIAA GNC Conference, Austin TX. Paper no 2003-5776.

Wilkinson, P.; Jenkins, B. 1999. Aviation Terrorism and Security. London: Frank Cass Publishers. 


\section{SKRYDŽIỤ SAUGUMĄ PADIDINAČIOS SISTEMOS IDE்JA}

\section{T. Rogalski}

S a n trauka

Straipsnyje pateikta valdymo iš oro sistemos koncepcija, kuri gali padidinti bendrosios aviacijos orlaivių saugumą bei aptartos pavyzdinès grèsmès bendrosios aviacijos orlaiviuose. Aprašoma sistema stebi lakūno kabinoje rodomus ịvairius skrydžio parametrus ir, kilus bet kokiai grèsmei orlaivio saugumui, gali ji apsaugoti. Darbe pateikiami ir kompiuterizuoto elektrodistancinio valdymo sistemos pavyzdžiai, kurie taip pat gali apsaugoti orlaivi nuo jam kylančiu grèsmių. Ši sistema gali modifikuoti piloto valdymą taip, kad būtų pakoreguotas skrydis, o jei ir to neužtenka - sistema pajègi ir autonominiam skrydžiui, kuomet orlaivis yra nukreipiamas ị artimiausią ir saugiausią oro uostą be piloto pagalbos.

Reikšminiai žodžiai: bendroji aviacija, skrydžių saugumas, automatinis skrydis. 